\title{
Zajełdyz. 0 postkolonialnych aspektach Jakucji Jegora Radowa
}

\begin{abstract}
Zaeldyz. About postcolonial aspects of Egor Radov's Yakutia. The author analyzes the relationship between post-colonialism and postmodernism on the basis of Egor Radov's novel Yakutia. The two currents are interrelated and affect both the aesthetics and the structure of the works. Their Russian variants, due to their particular interpretation of the colonial issue, are very different from the Western models. Yakutia is an example of a postmodern novel in which the post-colonial context is a background for philosophical and socio-political reflections. The novel combines various motifs characteristic of the genre of dystopia, popular in Russian postmodernism.
\end{abstract}

Keywords: Radov, postcolonialism, Yakutia, postmodernism, dystopia

Dyskurs postkolonialny wywarł olbrzymi wpływ nie tylko na filozofię, lecz także na poetykę i estetykę postmodernizmu. Cechy kultury dominującej wpływają na wzajemne powiązanie i kształt obu zjawisk. Decydującego znaczenia nabiera przede wszystkim świadomość zachodzenia procesu kolonizacji i wrażliwość na jego rezultaty. O ile powiązania postkolonializmu i postmodernizmu w kulturach Europy Zachodniej i Stanów Zjednoczonych doczekały się wyczerpujących badań ${ }^{1}$, o tyle

* Adres do korespondencji: Instytut Filologii Wschodniosłowiańskiej, ul. Grota-Roweckiego 5, 41-205 Sosnowiec. E-mail: pmlaniewski@gmail.com.

${ }^{1}$ Wśród rosyjskich badaczy zajmujących się kwestią powiązań dyskursu poststrukturalnego i postmodernistycznego wskazać należy między innymi Madinę Tłostanową (Проблема мультикультурализма и литература США кониа ХХ века, Москва 2000), Marię Suchotinę („Продается местный колорит, или Комплексвины в «Богемелочей» Арундати Рой”, Вопросы литературы 2010, nr 2) czy Anatolija Kolesnikowa (Мировая философия в эпоху глобализации, Нью-Йорк 2008). 
kwestia wpływu dyskursu postkolonialnego na postmodernizm w Rosji wciąż wymaga wnikliwej analizy.

Jednym z najciekawszych tekstów wykorzystujących tę zależność nie tylko w warstwie estetycznej, lecz także kompozycyjnej, jest Jakucja (Якутия, 1993) Jegora Radowa. Autor debiutujący w 1989 roku powieścią Zmiejesos (3мeecoc, 1992) należał do czołowych przedstawicieli rosyjskiego postmodernizmu lat dziewięćdziesiątych, w swojej twórczości wykorzystywał szerokie spektrum modeli i motywów charakterystycznych dla twórców postmodernistycznych, w tym wyszukane połączenia rozważań filozoficznych z formami charakterystycznymi dla literatury popularnej oraz inspiracje cyberpunkiem, postpunkiem i postapokalipsą.

Jegorow znakomicie odwzorowuje sieć postkolonialnych zależności charakterystycznych dla Rosji lat dziewięćdziesiątych. Istotne dla zrozumienia stopnia zawiłości tych relacji jest podkreślenie cech sowieckiego i posowieckiego dyskursu postkolonialnego. Na dobrą sprawę jako samodzielny byt mógł zaistnieć dopiero po rozpadzie Związku Sowieckiego i pluralistycznych, liberalnych reformach. Przez setki lat był wypierany ze zbiorowej świadomości, dominujący dyskurs państwowy odcinał się jednoznacznie od kolonialnych kategorii, widząc w nich poważne zagrożenie dla bezpieczeństwa kraju, niejednolitego pod względem narodowościowym i etnicznym. Państwo komunistyczne, początkowo jawnie występujące przeciwko negatywnym wpływom carskiej misji kolonizacyjnej, bardzo szybko zaczęło wykorzystywać i rozbudowywać jej aparat. Rosyjska sytuacja kolonialna diametralnie różniła się od tej, która charakteryzowała imperia zachodnie. Wynikało to w głównej mierze ze względów geograficznych - w przeciwieństwie do nich Rosja włączała podbite ziemie i ludy do swojego terytorium, nie oddzielały jej od nich morza i oceany, bezkres jej ziem rozpoczynał się w Europie Środkowo-Wschodniej i w pewnym momencie sięgał aż do Alaski, nazywanej Rosyjską Ameryką. Ludność — dobrowolnie lub na mocy politycznych rozporządzeń - mieszała się z sobą, łączyła w ramach jednostek noszących jawnie kolonialny wymiar początkowo wiejskich obszczin, a następnie systemu sowchozów i kołchozów. Z tego powodu jeden z najważniejszych badaczy rosyjskiego postkolonializmu - Aleksandr Etkind - parafrazując słowa dziewiętnastowiecznego historyka Sergieja Sołowiowa, określa Rosję mianem „kraju, który się kolonizuje”2. To sformułowanie wskazuje na specyficzny wymiar samego procesu kolonizacji - wektor podporządkowania biegnie w obu kierunkach: Rosjanin tak w czasach konserwatywnego samodzierżawia, jak pozornie postępowego komunizmu był (i jest nadal) zarówno jej obiektem, jak i narzędziem. Ta „wewnętrzna kolonizacja” generuje zespół charakterystycznych cech wpływających trwale na obraz rosyjskiego socius:

Колонизация всегда связана с попыткой освоить чужое, а ее неудачи и срывы приводили к размножению объективирующих дискурсов о своем. Если ощущение невозможности стать своим среди чужих часто сопровождало неудачи внешней колонизации, то ощущение себя чу-

2 А. Эткинд, Внутренняя колонизация. Имперский опыт России, Москва 2013, s. 90.

Miscellanea Posttotalitariana Wratislaviensia 8, 2020

(C) for this edition by CNS 
жим среди своих оказалось постоянной формой недовольства и протеста, связанных с ситуацией внутренней колонизации ${ }^{3}$.

Realizowany w wielu wymiarach motyw obcości w (pozornie) swoim państwie staje się dominantą kompozycyjną powieści Jegorowa. Sama Jakucja przeobraża się natomiast w idealne pole gry, w to, co Derrida określa mianem „przestrzeni inskrypcji”, charakteryzując ją w następujący sposób:

Jeśli struktury istnieją — pisze Derrida w Force et signification - to możliwe one są jedynie dzięki tej fundamentalnej strukturze, która sprawia, że całość [totalite] otwiera się i przepełnia tak, że nabiera sensu, antycypując telos, który tu należy rozumieć w znaczeniu najbardziej nieokreślonym. Z pewnością otwarcie to wyzwala czas i genezę (a nawet nakłada się na nie), jest jednak także tym, co ryzykuje powstrzymanie przebiegu. Skrępowanie siły formą ${ }^{4}$.

Jakucja w takim ujęciu zyskuje dwojakie znaczenie: z jednej strony — pod względem strukturalnym - jest idealną infrastrukturą o „preontologicznym i prelogicznym statusie”, czyli strukturą, która „nie będąc bytem, nie jest niebytem” służącą jedynie wydobywaniu sprzeczności, problematyzowaniu kategorii obecności, wskazywaniu na czystą różnicę. To w niej dochodzi do syntetycznego łączenia różnorodnych pojęć i znaczeń, wyodrębniania najmniejszych możliwych jednostek ${ }^{6}$. Z drugiej strony - wypełnia ważną funkcję z ontologicznego punktu widzenia. Bezkresne, poprzecinane blisko 700 tysiącami rzek i 800 tysiącami jezior połacie wiecznej zmarzliny przeobrażają się w idealną manifestację centralnej dla postmodernizmu kategorii pustki, która w lacanowskim ujęciu tożsama jest z Realnym. Jak przekonuje Slavoj Žižek:

Realne jest [...] samo w sobie dziurą, luką, otworem w samym środku porządku symbolicznego — brakiem, wokół którego jest ustrukturyzowany porządek symboliczny. [...] Realne jest [...] pozytywną bezwładną daną, która nie poddaje się negacji, nie może być ujęta przez dialektykę negatywności. Nie może być zanegowane, ponieważ już w sobie samym, w swojej pozytywności, nie jest niczym innym jak ucieleśnieniem czystej negatywności, pustki ${ }^{7}$.

Tego typu „infrastruktura” (można ją nazwać „infrastrukturą zerową”) zajmuje ważne miejsce także w innych utworach rosyjskiego postmodernizmu. W Małym palcu Buddy (Чапаеви Пустота, 1996) Wiktora Pielewina terytorium Mongolii Wewnętrznej umożliwia transcendentalne poznanie istoty rzeczy, syberyjski lód staje się centralną kategorią Trylogii Władimira Sorokina, na jej terytorium znajduje się także laboratorium odpowiedzialne za produkcję tajemniczej substancji w powieści Niebieska słonina (Голубое сало, 1999), a wątek syberyjski otwiera zespół postkolonialnych zależności w ŻD (ЖД, 2010) Dmitrija Bykowa.

\footnotetext{
${ }^{3}$ Ibidem [kursywa autora].

${ }^{4}$ M.P. Markowski, Efekt inskrypcji. Jacques Derrida i literatura, Bydgoszcz 1997, s. 109.

5 Ibidem, s. 110.

6 Ibidem, s. 111.

7 S. Žižek, Wzniosty obiekt ideologii, przeł. J. Bator, P. Dybel, Wrocław 2001, s. 202.
}

Miscellanea Posttotalitariana Wratislaviensia 8, 2020

(C) for this edition by CNS 
Szczególna ontologiczna, metafizyczna i strukturalna rola Jakucji wynika w głównej mierze z jej geograficznych i społecznych charakterystyk. Republika Sacha zajmuje powierzchnię $3,1 \mathrm{mln} \mathrm{km}^{2}$, co czyni ją największą jednostką podziału terytorialnego na świecie, ponad $40 \%$ jej terytorium leży za kołem podbiegunowym, dwie trzecie powierzchni zajmują góry i pogórza, jedynie $1 \%$ gruntów może być wykorzystywane w rolnictwie, a łączna długość rzek wynosi około 2 mln kilometrów. Krajobraz regionu składa się w zdecydowanej większości z lasów tajgi (80\%), na pozostałe $20 \%$ przypada lasotundra, tundra i pustynia arktyczna. Jednocześnie Sacha dysponuje jednak olbrzymimi bogactwami naturalnymi — znajdują się w niej bogate pokłady węgla kamiennego, ropy naftowej i gazu, wydobywane jest $95 \%$ rosyjskich diamentów. Na wielkim obszarze żyje jedynie 958,5 tys. ludzi. Większość stanowią Jakuci (49,9\%), dopiero za nimi plasują się Rosjanie $(37,8 \%)$ i przedstawiciele innych narodowości (ich łączną liczbę szacuje się na ponad 120$)^{8}$. Powieść Radowa obfituje w różnego typu odniesienia do tych charakterystyk. Jednocześnie - w przeciwieństwie do zeuropeizowanego zachodu imperium - Jakucja wciąż jest przestrzenią w znacznej mierze plemienną i koczowniczą, sprzeciwiającą się terytorializacji charakterystycznej dla utrwalonego aparatu państwowego. Za sprawą posiadanych bogactw naturalnych wciąż jest także obiektem działań kolonizacyjnych i terytorium wyjątkowo niebezpiecznym, grożącym ciągłą rewolucją.

Utwór umiejscowiony w wizji postkomunistycznej przyszłości wpisuje się w szeroki paradygmat refleksyjnych, filozoficznych antyutopii charakterystycznych dla drugiej i trzeciej fali rosyjskiego postmodernizmu. O jego awangardowym charakterze świadczą chociażby otwarte nawiązania do gatunku cyberpunku i wyszukane powiązania z motywami charakterystycznymi dla literatury wysokiej oraz klasyki literatury rosyjskiej. Z postkolonialnego punktu widzenia szczególnie interesujące wydaje się jednak umiejscowienie akcji w hiperrealistycznej przestrzeni Jakucji, odczytywanej przez bohaterów jako najwyższa forma wcielenia. Ten aspekt zostaje podkreślony już w inwokacji otwierającej utwór, następnie ponawia się niemal refrenicznie, wykazując między innymi analogie między Jakucją i Bogiem lub Jakucją i rajem:

Мир есть мое развлечение. Якутия вырастает из всего, как подлинная страна, существующая в мире, полном любви, изумительности и зла. Она таит в себе тайны и пустоту, обратимую в любое откровение этого света, который присутствует здесь, как неизбежность, или сущая красота, прекрасная, словно смысл чудес. Слава есть откровение ее образа; тайна есть ее истинное бытие; легенда есть ее высшая цель; [...] Ее земля подобна огню, или волшебному коню, летящему в рай. Ее земля подобна незыблемости срединного пути, разделяющего небо и землю. Ее земля подобна пашне, жаждущей семян и бороны. Ее земля подобна орлу, смотрящему на скалы с гордостью истинного царя выси. Ее земля простирается здесь, словно необъятная плоскость, служащая моделью для вечности. Ее земля покрыта белым льдом, как фатой новобрачной, и снег падает на ее поверхность беззвучно и легко, будто желая ее ласкать и любить ${ }^{9}$.

8 Wszystkie dane podaję za oficjalną stroną internetową Republiki Sacha: http://old.sakha.gov. ru/node/448 (dostęp: 24.07.2018).

9 Е. Радов, Якутия, http://www.kulichki.com/moshkow/akm/txt/radov/yakutia-1.html (dostęp: 23.07.2018). Dalej cytuję zgodnie z tym źródłem.

Miscellanea Posttotalitariana Wratislaviensia 8, 2020

(C) for this edition by CNS 
Apoteoza Jakucji nie ogranicza się wyłącznie do sfery mistycznej. Znajduje też bezpośrednie przełożenie na kategorie społeczno-polityczne. Jest określana jako „jedyny kraj", staje się paradoksalnym axis mundi, względem której pozycjonują się inne jednostki. Region funkcjonuje w niezwykle skomplikowanej sieci zależności. Jego największym wrogiem jest chyląca się ku upadkowi „Sowiecka Depia”, która uzurpuje sobie do niego prawo (to określenie jeszcze w czasach Związku Sowieckiego cieszyło się dużą popularnością wśród przeciwników komunizmu. Wywodzi się z obraźliwego określenia Rad Deputatów Ludowych — organów przedstawicielskich ZSRR [Советы народных депутатов]). Wprowadzony przez nią system rządów jest pogardliwie nazywany „leninszczyzną”, która zaburza naturalny bieg dziejów i doprowadza do rozbicia Jakucji. Swoje organizacje wojskowe i polityczne mają jednak również przedstawiciele innych nacji zamieszkujących bezkresne połacie wschodniej Syberii, w tym Ewenkowie, Eweni, Nieńcy, Komi czy Nanajowie. Każdy lud wytwarza absurdalne ramy państwowości opierające się na skrajnym nacjonalizmie i bliźniaczo podobnym dyskursie, u którego podstaw leżą groteskowe mitologie, wywodzące dzieje świata od istnienia konkretnej nacji. To właśnie płaszczyzna mitologiczna daje możliwość zaistnienia nacji (a w konsekwencji przybierającego na sile nacjonalizmu). Co charakterystyczne dla poetyki postmodernizmu również ona staje się obiektem groteskowej gry, tworzą ją fragmenty różnych kodów kulturowych, które wypełniają świadomość postsowieckiego człowieka - obcego wśród swoich, pozbawionego przynależności i punktów odniesienia, skazanego na ciągłą tułaczkę po terra nullius, które jednak nigdy nie przekształca się w terra repromissionis.

Rizomatyczną konstrukcję świata definiuje jego geneza, w której wszystkie terytoria podporządkowują się Jakucji, będącej ich rzeczywistą orbitą: w zaprezentowanej wizji kolejne ziemie - Ajp-sjurija, Wiest', Jakucja, Czukotka, Zajełdyz, Asza, Depija, obwód Seral, Austria, Pipija, Aaaaaaaa i Makija powstały z połączenia mamutów i dzieci. Na skutek kichnięcia jednego z nich Jakucja wyłoniła się i zaczęła nad nimi górować. Ważną rolę w proponowanej konstrukcji odgrywają też mity zaczerpnięte z kultury regionu - wielokrotnie przywoływany jest zwłaszcza mit o pierwszym Jakucie, Elleju Booturze, który spłodził naród, wybierając brzydszą, ale bardziej płodną z proponowanych mu dwóch sióstr. Jegorow decyduje się także na wplecenie w rizomatyczną tkankę utworu fragmentów podań o jakuckich bogach (Yysach), szamańskie obrzędy i święta.

Główny bohater utworu - Sofron Isajewicz Żukauskas - należy do Liberalno-Demokratycznej Republikańskiej Partii Jakucji (LDRPJa), której celem jest oddzielenie się od Sowieckiej Depii, sprzedaż całej Jakucji Ameryce i wydrążenie pod biegunem północnym Wielkiego Tunelu, który umożliwi wywożenie do metropolii bogactw naturalnych. W zamian Jakuci, jako obywatele Wielkiego Państwa Amerykańskiego, mieliby otrzymywać niezbędne do życia środki oraz, z pomocą technologii kosmicznych, zmienić orbitę Ziemi, tak aby podnieść temperaturę w słynącym z wysokich mrozów regionie. Dochodzi więc do paradoksalnej kolonizacji, 
która możliwa jest wyłącznie w warunkach rosyjskich: dobrowolnego kolonizowania się, świadomego, oddolnego tworzenia struktur umożliwiających metropolii ekonomiczny drenaż podbitych ziem. Taki modus bycia charakteryzuje w doskonały sposób postkolonialne i postimperialne społeczeństwo, które pozbawione dawnego centrum nie potrafi istnieć samodzielnie i jest zmuszone do poddania się obcym wpływom.

Tajne porozumienie opiera się na sieci agentów rozsianych po całym terytorium Jakucji — ostatni z nich ma znajdować się nad Oceanem Arktycznym, skąd kontaktuje się radiowo z amerykańskimi agentami. Żukauskas zostaje wysłany wraz z innym członkiem partii, Abramem Gołowko, na poszukiwania zaginionego łącznika. W tym celu bohaterowie przemierzają tysiące kilometrów i odwiedzają kolejne jakuckie miejscowości. Absurdalny charakter utworu podkreśla charakterystyczne dla porozpadowej mentalności poczucie rozbicia - owocem polityki kolonialnej najpierw carskiej Rosji, a następnie Związku Sowieckiego, jest zaistnienie zaproponowanej przez Etkinda kategorii obcego wśród swoich. Utopijne wizje wyrażają natomiast w wyjątkowo wyraźny sposób kryzys polityczny, jaki dotknął kraje należące wcześniej do ZSRR. Ani Żukauskas, ani Gołowko nie są Jakutami, nie są nimi również najważniejsi działacze stronnictw opowiadających się za niepodległością regionu. $\mathrm{Z}$ tego faktu wynika specyficzne podejście nie tylko do pojęcia ojczyzny, ale również szerszego kontekstu geopolitycznego: Jakucja przeobraża się w idealną terra nullius, umożliwiającą wytworzenie nowego systemu. Co znamienne - zupełnie inne znaczenie zyskuje w niej pojęcie rasy, które nie jest już determinowane biologicznie:

Победит общая якутская нация. Возникнет новая раса солнечно-северных людей. Советская Депия родит новую Якутию. Гора родит землю обетованную; из дерьма возникнет Бог! Армия будет с нами; она не захочет самоуничтожиться из-за каких-то различий носов, или характеров. Все эти народы вольются в одну большую якутскую семью; и ореол великого будущего воссияет над этой радостной, счастливой страной!

- Да ты - коммунист, Софочка! — рассмеялась Надя, поставив перед Жукаускасом тарелку с глазуньей из двух яиц. - Ты просто настоящий красный!

— Не называй меня так! — крикнул Софрон, стукнув ладонью по столу. — Я — якутянин! Я есть истинный якутянин, и я желаю блага своей Родине! Ты помнишь что говорил великий якутский патриот и писатель Иван Мычаах? « Я зрю сквозь века... Я вижу счастливый свой народ на прекрасной земле, которая зовется моей Родиной, и которая могущественна и свободна. Я вижу его расцвет и величие; и я вижу его равным среди самых больших народов нашей планеты, и никакой враг не смеет грозить ему. Я вижу это так, как я вижу солнце, или небо, или зеленую траву летом, и я убежден, что будет так. » А?

— Да ты — националист, Софик, - хихикая, сказала Надя, — но у тебя нет узких глаз. Ничегоневыйдет!

Żukauskas przystępuje do partii, aby zrealizować osobisty plan zemsty: żona zdradza go na jego oczach $\mathrm{z}$ oficerem KGB. Co znamienne - miała ulec mu pod presją reprezentowanej przez niego władzy („Powiedział: ssij, bo wsadzę cię za propagandę przeciwko Sowieckiej Depii”). Uwagę zwraca też sam stosunek oralny, który 
może symbolizować podporządkowanie aparatu mowy osoby kolonizowanej woli kolonizatora. Wkrótce okazuje się jednak, że funkcjonariusz także przystępuje do LDRPJa i, jak sam deklaruje, „jest aktywnym działaczem i kocha Jakucję”. Postkolonialne rozbicie można zaobserwować w jeszcze wyraźniejszej formie u Abrama Gołowki. Mimo że jest jednym z założycieli Liberalno-Demokratycznej Partii Jakutii, wielokrotnie wygłasza sprzeczne poglądy polityczne i społeczne, wpada w okresowe paranoje. W idealny sposób obrazuje stan psychiki jednostki, która musi odnaleźć swoją tożsamość w rzeczywistości zmuszającej ją do nieustannego konfrontowania się z obcymi. Gołowko jest z pochodzenia Żydem (wskazuje na to już jego imię) - i upatruje cech idealnych w Izraelu, który w jego rozumieniu staje się axis mundi:

Ведь я - еврей, я всегда был счастлив и рад, что я - именно еврей, представитель Божеского народа, а оказалось, что это то же самое, что и землеройка, коммунизм, или большая свеча. Я ехал с вами ради своей цели, я в чем-то обманул вас всех [...], всю нашу ЛДРПЯ (тоже пример идиотизма - надо же вообразить такое название!!); ведь я плевать хотел на вашу Америку, и Якутия мне тоже постольку поскольку; ведь главный смысл и цель моей жизни был всегда Великий Израиль; ведь я - Абрам, Авраам, я ношу это прекрасное имя, и я должен быть достойным его!!

Gołowko - tak jak inni bohaterowie - swobodnie przekształca i łączy z sobą wybrane mitologemy. Wpisuje jakuckie podania w rejestr semiotyczny charakterystyczny dla kultury Izraela, unieważnia wcześniejsze poglądy i deklaracje, wyśmiewa plany partii tylko po to, by po chwili obrócić wszystko w żart. Charakteryzujący się neofickim fanatyzmem i żądzą sławy Żukauskas chętnie bierze udział w pantomimie, w którą - zgodnie z postmodernistycznymi postulatami - przeobraża się właściwie cały tekst. Co ciekawe (i w pełni zrozumiałe z kompozycyjnego punktu widzenia) - Jakucja jest z jednej strony bytem idealnym, mającym indywidualne cechy, z drugiej jednak zamienia się w przestrzeń uniwersalną - kulturowe czyste pole, na które można nanieść dowolną inskrypcję. Znakomicie ilustruje to paranoidalna wizja Gołowki:

Ибыл Эллэй. Надальнем Юге, средигор, степейио зержил большой человек, которого звали Эллэй. Он знал, что он рожден Великим Израилем, он был обрезан и говорил по-арамейски, и у него была книга; но он знал, что из всего вырастает Якутия, как подлинная страна, существующая в мире, полном любви, изумительности и зла.

To zagubienie, charakterystyczne dla człowieka poddawanego mnogości radykalnych, imperialnych dyskursów, doprowadza do jego rozbicia. Efektem kolonizacji, a właściwie efektem charakterystycznego dla Rosji nieustannego kolo nizow a nia się, jest pomieszanie kodów kulturowych, ich fragmentaryzacja, zaburzenie naturalnych procesów i odruchów. Gołowko - jednocześnie Żyd, obywatel Depii i Jakutianin — jest poddawany wpływom przynajmniej trzech wielkich (i dziesiątek mniejszych) ośrodków dyskursywnych. Ciąg manipulacji i przekształceń kończy się finalnym (chociaż czasowym) rozbiciem, zagubieniem, poplątaniem kodów, zachwianiem całego systemu wartości jednostki: 
— [...] Где моя глупость, где моя религия, где моя война!.. Неужели, Израиль - то же самое, что и Советская Депия, только с другой стороны?! И что тогда есть Якутия? А может, она и есть все?!!

- Ах вот вы какой, - сказал Софрон Жукаускас, выслушав эту тираду. - Когда мы прилетим, я все о вас сообщу. Или вам лучше лечь в психбольницу?!

Szczególnego znaczenia nabiera - centralna pod względem strukturalnym groteskowa scena, w której bohaterowie próbują przedostać się do miasta Ałdan, będącego bazą samozwańczego cara Jakucji. Zamordystycznym rządom nie chcą podporządkować się inni mieszkańcy regionu - Ewenowie, Ewenkowie, Rosjanie, komuniści, a nawet część rdzennych Jakutów, którzy w odpowiedzi tworzą własne jednostki. Doprowadzona do skrajności iteracja, opierająca się na powtarzaniu tych samych wypowiedzi przedstawicieli kolejnych nacji, obnaża cechy imperialnego dyskursu - jego schematyzm, otwartą konfrontacyjność, tendencyjne podejście do mitologii, która, zgodnie z rozumowaniem Rolanda Barthes'a, w określonym politycznym użyciu przeradza się w agresję ${ }^{10}$.

W scenie oprócz Żukauskasa i Gołowki uczestniczą mocno utożsamiający się z opcją jakucką (chociaż niemający z nią wiele wspólnego) schizofreniczny poeta Yyra oraz prorosyjski kierowca Iwan. Ich autobus w pewnym momencie zatrzymują uzbrojone wojska Narodowego Frontu Wyzwolenia Ewenkii, rozpoczynając tym samym iteracyjną pętlę, która będzie wyróżniać się powtarzaniem nie tylko całych partii dialogowych, lecz także tworzonych i deformowanych mitologemów, filozofemów, koncepcji polityczno-społecznych:

Здравствуйте. Я - младший лейтенант Энгдекит, Национальный фронт Освобождения Эвенкии. И прошу сразу иметь в виду: мы - не тунгусы, мы - эвенки! Куда направляетесь?

- В Алдан, - вежливо улыбаясь, ответил Головко, — к другу на свадьбу.

- К другу? Свадьба? А друг, наверное, якут...

- Да нет...

— Ясно! — прогремел Энгдекит. - А вы откуда?

- Я - поэт! - сказал Ырыа.

- А что вы делаете на территории Эвенкии?

- Я?.. Живу.

- А почему вы не сражаетесь с русскими, якутами, эвенами, советскими?

- У меня... статья.

- Вы - дебил?

- Я - поэт!

— Ясно... - проговорил младший лейтенант, подойдя к шоферу. - Вас я, кажется, знаю. Вы из Нерюнгри. Наш главный враг.

- Да я сам эвенк... - хмуро сказал шофер. - Во мне есть кровь эвенкийская... Я всегда был за вас, я просто вез их, для вас...

Ostatecznym wyrazem charakterystycznego dla postmodernizmu rozbicia metanarracji i zastąpienia stabilnego centrum pustką jest świadoma i brutalnie oczywista podmiana głównych kategorii. Ewenkia w każdym momencie może zastąpić Jakucję

${ }^{10}$ K. Kłosiński, „Sarkazmy”, [w:] R. Barthes, Mitologie, przeł. A. Dziadek, Warszawa 2008, s. 7. 
(„Эвенкия произрастает во всем, как истинная страна, существующая в мире, полном величия, счастья и добра [...]”), podobna zależność dotyczy również Ewenii („Единственный морозно-северный подлинный народ - это эвены. Наша территория огромна; раньше она простиралась до южного моря и до западных сверкающих огней”), Rusi („мир - это Русь, и любовь - это Русь, и хлеб это Русь, и песня - это Русь, и Бог - это Русь, и я - Русь. И безменя Русь не наполнена, не целиком, невся") i każdego pojęcia, które zostanie na mocy dyskursywnej siły przeniesione do centrum układu. To właśnie z tego powodu świadom pustki Gołowko rozpacza nad nieobecnością swoj ego Boga, religii i narodu. W przeciwieństwie do naiwnego i słabego Żukauskasa zdaje sobie bowiem sprawę, że w rzeczywistości te - pozornie różne - zjawiska reprezentują tę samą ośmieszoną i niewiarygodną metanarrację.

Prezentowana iteracja dochodzi do własnych granic w chwili, gdy narracja zamienia się w stworzony przez Yyra wiersz podwójny, który, jak przekonuje, ma starojakucki rodowód („Онионне был и не был Софрономи Софроном Исаевичеми Исаевичем Жукаускасоми Жукаускасом, он был и был эвенкийцем и эвенкийцем"). W ten sposób zostaje obnażony brak stabilności, pustka spowodowana usunięciem centralnej kategorii (w tym przypadku wytworzonej przez maszynę imperialną kategorii ojczyzny), noszącej wyłącznie symulakryczny charakter, a zamykającej się w pełni w wymiarze znakowym. Podobny charakter noszą inne konstrukty stworzone przez chorego psychicznie poetę. Jego zabawa słowem dekonstruuje całą tkankę znakowości, rozrywa wszystkie napotkane struktury. Yyra wymyśla język starojakucki, w którym tworzy swoje poematy (znajomość samego języka jakuckiego nie jest mu jednak do niczego potrzebna), tworzy formy poetyckie będące, jak przekonuje, formami charakterystycznymi dla dawnej kultury Jakutów. W przeciwieństwie do towarzyszy podróży pragnie tortur i śmierci, traktując je jako atrybuty swojej twórczości:

Я — поэт! — гордо заявил Ырыа. — Я — творец искусства. Перед своей несостоявшейся смертью я написал великое стихотворение: «Капошаварара». Я хочу в Алдан, потому что там война, и мне все равно. Я не хочу в Алдан, я хочу быть звеном, или эвенком, а еще мне нравится печатать на пишущей машинке огромный идиотский роман, в котором в принципе заключено все, но в такой дебильной форме, что хочется просто подтереться черно-белыми страницами. Пойдем тегулять в лес?!

Yyra jest schizoidalną maszyną rozrywającą paranoidalne zestawienie. Ostatecznie w podwójny sposób realizuje swój instynkt śmierci: w czasie transportu do bazy cara Jakutów morduje bohaterskiego Gołowkę, który wytrzymuje okrutne tortury przeprowadzane zarówno przez Ewenków, jak i przez Ewenów („Это я! — воскликнул он. - Я убилего и сказал: «Кусысы!» Это мое произведение; это искусство. Я на конец создай!”), a następnie w niemal seksualnej ekstazie poddaje się rytualnemu ukrzyżowaniu, wykrzykując przed śmiercią zupełnie absurdalne w tym kontekście słowo „Ямаха”. 
Po Ewenkach porwanych bohaterów przejmują Ewenowie. Ma miejsce niemal takie samo cięcie („Мы - эвены! Мы сражаемся за свободу Великой Эвении! Мы должны сбросить наконец ярмо русских, советско-депских, эвенкских, юкагирских и якутских самозванцев. Единственный морозно-северный подлинный народ — этоэвены”), kopiowaniu ulegają nawet niektóre partie dialogowe (w przypadku zarówno Ewenków, jak i Ewenów pojawia się taka sama wypowiedź: "- Онврет. Он считает, что все - Русь. - Русь? - переспросил Часатца. Что это? - Ну, Россия. - Ах, Россия... - ухмыляясь, проговорил Часатца, хлопнув в ладоши").

Owa destrukcyjna iteracja jest najbardziej widoczna w opisie groteskowo brutalnych tortur i kar wymierzanych przez przedstawicieli kolejnych narodów. Ewenkowie stosują metodę, którą nazywają „притырка”:

Будемтебя, человечек, притыривать. Это наше новое эвенкское изобретение. Это просто. Притырка похожа на насос. Туда, в толстый конец, залита едкая злая кислота. Трубка притыривается тонким концом в какое-нибудь нежное место пытаемого, и потом - yx! - резкое нажатие на ручку, струя кислоты устремляется вперед и внедряется в тело.

Zwaśnieni z nimi Eweni nieprzypadkowo posługują się bliźniaczą konstrukcją: „Присыпка - это наше эвенское изобретение. Мы делаем рану, а потом сыпем на нее специальный гадкий порошок, который разъедает все кости. Это очень больно; это даже не соль, а вообще нечто ужасное. Не будешь говорить?”. Niemal jednakowe, komiczne opisy dekonstruują państwowy dyskurs, wykorzystywany przez imperia zwłaszcza w pierwszym etapie ich tworzenia i rozwoju. Jeszcze bardziej kompleksowy opis zyskuje wymierzana przez Ewenków kara śmierci („„Заворачивание"), której sens sprowadza się nie tylko do okrutnego pozbawienia skazanego życia (umieszcza się go w specjalnej konstrukcji i - zgodnie z nazwą - zawija się, łamiąc kości i miażdżąc tkanki miękkie), lecz także do stworzenia szczególnego rodzaju pośmiertnego rytuału przejścia - ciało miele się i „wpycha w dupę łosia”, co jest, według tradycji, najwyższym wyrazem uznania dla zmarłego, który w kolejnym życiu odrodzi się jako Ewenk.

W owej scenie Jegorow gromadzi zespół cięć charakterystycznych dla rodzącego się imperium. Ich nagromadzenie, oczywista sztuczność i doprowadzona do skrajności iteracyjność skutkują autodekonstrukcją imperialnego dyskursu. Cały proces sprowadza się do zapisu, któremu kolejne maszyny państwowe poddają zewnętrzne elementy. Tę samą zależność obserwują Deleuze i Guattari, odnotowując, że „społeczeństwo nie ma natury wymiennej, socius ma charakter zapisujący: nie zamienia ciał, lecz naznacza te należące do ziemi"11. To z tego powodu ciało Gołowki pod wpływem tortur zamienia się w krótkim czasie w zespół nacięć i pęknięć, a tchórzliwy Żukauskas znaczy sam siebie własnym kałem („Авотивы! — весело крикнул Илья, увидев окровавленного Абрама и обосравшегося Софрона”). W schizo-

11 G. Deleuze, F. Guattari, Anty-Edyp. Kapitalizm i schizofrenia, przeł. T. Kaszubski, Warszawa 2017, s. 218. 
analizie ten proces wywodzony jest z nietzscheańskiej koncepcji „przedhistorycznej pracy ludzkości: użyciu najokrutniejszej mnemotechniki na żywym ciele po to, by ustanowić pamięć słów, opierając się na wyparciu dawnej pamięci biokosmicznej"12. W większym ujęciu całe życie społeczne przeobraża się w nieustanny ciąg tresury i tortur, co doskonale ilustruje system wprowadzony przez zamordystyczną jakucką tyranię, a w groteskowy sposób dekonstruuje karykaturalnie neoliberalna koncepcja proklamowana przez LDRPJa. Wykrystalizowanie czystego aparatu terroru, pozbawienie dyskursu państwowego jakichkolwiek konkurentów i zamknięcie się wyłącznie w imperiotwórczym paradygmacie pozwala na skrupulatne prześledzenie tych zależności. Twórcy Anty-Edypa przedstawiają swoją wizję w następujący sposób:

Cała niedorzeczność i arbitralność praw, cały ból inicjacji, cały ten perwersyjny aparat represji i edukacji, rozgrzane żelazo i straszliwe procedury, nie mają innego celu niż wytre sow anie człowieka, naznaczenie jego ciała, uczynienie go zdolnym do aliansu, wykształcenie w nim relacji wierzyciela z dłużnikiem, która okaże się w przypadku każdej ze stron kwestią pamięci ${ }^{13}$.

W ten schemat z pewnością najodważniej uderza szalony poeta Yyra, który całość swojego popędu śmierci kieruje przeciwko państwowej maszynie. Jego pożądanie cierpienia zawstydza imperialne oko, które „z bólu czerpie przyjemność”14, sprawia, że nieskończony ciąg coraz okrutniejszych tortur traci sens, państwo nie jest już zdolne do nanoszenia swojej inskrypcji. Co więcej, przez bezsensowne odebranie życia Gołowce Yyra nie tylko stawia siebie ponad prawem, lecz przejmuje także kompetencje władcy — jedynej osoby uprawnionej do decydowania o życiu lub śmierci. Czyni to, gdy nic mu już nie zagraża (znajduje się w rękach swoich pobratymców), dopiero wtedy zaciąga jednak rzeczywisty dług, wpisuje się w prostą, imperialną kalkulację: „wyrządzona krzywda = ból, któremu należy się poddać” ${ }^{15}$. Być może właśnie $\mathrm{z}$ tego powodu wymierzona mu kara pozbawiona jest głębszego rytualizmu, nie jest już aktem państwotwórczym (taki sens moglibyśmy przypisać ewenkijskiemu umieszczaniu zmielonych zwłok skazańców w odbycie łosia). Ukrzyżowanie jest jedynie kalką, czystym symulakrum pozbawionym jakiegokolwiek desygnatu. Ten fakt podkreśla również ostatnie, obłąkańcze słowo skazańca, będące finalnym wyrazem państwowego rytualizmu. Yyra - poeta tworzący własne schizoidalne mity - nie chce wpisywać się w jego paranoidalne ramy.

Drugie pęknięcie w tym układzie rozgrywa się bezpośrednio w tkance języka. Najwyższą formą jego dekonstrukcji jest wskazana wcześniej podwójna poezja Yyra oraz niebędący nośnikiem jakiegokolwiek znaczenia, opierający się na prostych sylabach język starojakucki. W utworze istnieje jednak wiele kategorii pośrednich, które sprawiają, że cała tkanka języka staje się dyskursywnym aparatem imperium, przeradza w czysty system przyporządkowywania i hierarchizacji. To dlatego swoistym

\footnotetext{
12 Ibidem.

13 Ibidem, s. 224.

14 Ibidem, s. 225

15 Ibidem, s. 226.
} 
kontrapunktem do rozbudowanych form stają się monosylaby („puk-puk”, „pis'-pis"”) lub brzmiące egzotycznie, ale pozbawione znaczenia zapożyczenia z języka jakuckiego. Ta płaszczyzna ma także bezpośrednie przełożenie na dekonstrukcję płaszczyzny polityczno-społecznej, a szerzej również na pojmowaną całościowo ontologię opierającą się na sztywnych, metanarracyjnych, normowanych kulturowo wzorcach. Zwraca na to uwagę chociażby samozwańczy car Jakucji:

Какая разница, комитет «Ысыах», или «Писиах»; «Якутия», или «Якотия»? Называйся хоть «пись-пись», но имей бомбочку. Язык - говно, он вообще постоянно меняется, метафизика тоже говно, религия - тоже. И Бог - говно, хоть мы ему и молимся. Все это для собственной убедительности придумано, чтобы не стыдно было солдатику отдать свое здоровье, или жизнь за меня. Но на самом деле он все понимает. Есть просто абстрактная земля, почва, можешь ее и взять и понюхать, и ты поймешь, что она пахнет говном. А потом можешь назвать ее Якутией, Эвенкией, или вообще Кусысы. И объявить своей. В этом все и дело. Главное, что ты объявил се своей. И ты что, думаешь, я — такой великий якут? Да их вообще не существует, это просто какие-то отколовшиеся тувинцы. Ну, если ты сейчас оскорбишь мою национальную гордость, я конечно же буду страшно возмущен и так далее, но это ведь — кровь, бессознательное, это как если мне на ногу наступят, я сразу же машинально дам в харю.

Kluczem do odczytania rozbudowanego dekonstrukcyjnego schematu jest słowo „Заелдыз”, służące jako tajne hasło umożliwiające protagonistom kontakt z łącznikami (co znamienne - wszystkie osoby wykorzystują jedno hasło, co w oczywisty sposób demaskuje sztuczność konspiracji). To w tym słowie zamyka się niemal cały groteskowy ciąg fabularny, który jednocześnie poddaje dekonstrukcji nie tylko dyskurs kolonialny i imperialny, ale także dyskurs neoliberalny oraz romantyczny, a w szerszym ujęciu także metafizyczny i metanarracyjny.

Radow zgodnie z postmodernistyczną logiką odwraca hierarchię wartości, podporządkowuje całość ważnych ze społecznego punktu widzenia zjawisk (kategorie ojczyzny, walki narodowowyzwoleńczej, ideałów, religii) prostemu schematowi erotycznemu. W rzeczywistości śmiertelnie niebezpieczna misja, na którą przewodniczący partii Drobacha wysyła Żukauskasa i Gołowkę, ma jedynie umożliwić mu swobodne kontynuowanie romansu z żoną Żukauskasa. Co więcej — okazuje się, że kobieta sama jest tajną agentką i wykorzystuje swoją pozycję do podejmowania stosunków seksualnych z niezliczoną liczbą werbowanych przez nią na terytorium całej Jakucji mężczyzn. Nieporadny, otumaniony dyskursem i żądzą politycznego sukcesu Żukauskas („За секретаршу я готов все сделать”) wypiera jednak świadomość rozwiązłości małżonki i wierzy w kolejne kłamstwa, motywowane komicznymi, pseudopaństwowymi hasłami, co staje się zresztą obiektem żartów jej kochanków. Paralelnie z groteskową linią erotyczną rozgrywa się równie groteskowa linia imperialna. Do splecenia obu dochodzi w jednej z ostatnich scen utworu: po cudownym powrocie do Jakucka okazuje się, że rozpadła się Sowiecka Depia, a władzę w nowym państwie (które zyskuje nazwę „Свободноякутская Сажреспублика УрьянХай”) przejmuje zarządzany przez Drobachę komitet. W trakcie jego posiedzenia pod wpływem czystego dyskursu dochodzi do nieoczekiwanej seksualnej eksplozji: 
jedna z kobiet, słuchając słów działacza, zaczyna się masturbować, a otumaniona publika jedynie potęguje atmosferę erotycznego napięcia. Sam Żukauskas zostaje wysłany na kolejną, tym razem samotną misję. W jej trakcie dowiaduje się, że zwycięstwo Jakucji jest fikcją. Statek, który powinien nosić imię jego dawnego towarzysza, bohatera państwowego Gołowki, zmienia nazwę na „Komi”, z kolei w Niżniejansku, w którym rezyduje ostatni agent, wciąż panuje komunizm (Żukauskasa wita w nim napis „Мы придем к победе коммунистического труда! Ленин”). Błyskawicznie okazuje się również, że jego odpowiedzialny za nawiązanie łączności z Ameryką współpracownik jest chory psychicznie, a udostępnione mu radio nie działa. Dopiero w tym momencie, jakby pod wpływem zbyt dużej liczby dyskursywnych bodźców i zbyt gwałtownie rozszerzającej się entropii, osobowość Żukauskasa się rozpada - dochodzi do metamorfozy niemal w zupełności kopiującej główny motyw konstytutywnej dla myśli postmodernistycznej Przemiany Kafki. Całkowita redukcja wydaje się w paradoksalny sposób łączyć dwa stadia opisane przez Deleuze’a i Guattariego - stawianie-się-zwierzęciem i ekstatyczne stawanie-się-wszystkimi. Żukauskas przekształca się jednocześnie w Boga (z jednej strony w Boga-Jakucię, z drugiej w Boga-metanarrację, który stracił swoje raison d'être) oraz w chrząszcza biegacza. Poza tym transgresyjnym aktem nie ma już jednak, w przeciwieństwie do tekstu Kafki, żadnej nadziei na odrodzenie czy na powrót do ludzkiej formy, nikt nie może przyjść mu z pomocą i uzasadniać w jakikolwiek sposób jego egzystencji. Nie istnieją stadia pośrednie, nie istnieje zasadniczo nic poza aparatem imperialnym. Jednostki funkcjonują tak długo, jak długo są w stanie grać kategoriami wprowadzanymi przez kolonialny i imperialny dyskurs, umykać przed historią, nie doprowadzać do jej rozpoczęcia. To z tego powodu w powieści Radowa wszystko tkwi w zawieszeniu Depia ciągle się rozpada, ale nigdy się nie rozpadnie, Jakucja tkwi w ciągłym starciu z Ewenią, Ewenkią, Komi i dziesiątkami innych struktur tylko po to, żeby nie móc zaistnieć i nie móc rozpocząć biegu historii. Ten bowiem nie kończy się, ale rozpoczyna unicestwieniem:

- Ну, иктожея? - подозрительноспросилСофрон, слегкаотступаяназад.

- Вы есть Верховная Личность Бога, то есть, собственно Бог. Я не знаю, зачем вы здесь в этом облике; я знаю, что пути неисповедимы и все такое, но это я знаю точно, да и вы - слава Богу! ха-ха - это знаете. - Вы правы, — сказал Софрон Жукаускас.

- Я - Бог. Мне нравится Мое нисхождение, деградация, маразм. И Я это осуществил так, чтобы не помнить. Но теперь эта история закончилась, вас Я сделаю жойным наместником, а сам останусь здесь. Наиболее чудесное из всего увиденного в этом усечении - несомненно, Нижнеянск. Вот здесь и будем, только хочется еще меньшего, более дурацкого, интересного. Спасибо за чай! До свидания!

И он тут же превратился в жужелицу.

Symboliczne (chociaż, oczywiście, równie pozorne) domknięcie paradygmatu czasowego ma zresztą miejsce nieco wcześniej - dochodzi do niego na skutek zrzucenia przez radzieckie wojska bomby atomowej na miasto Ałdan („внизу невдалеке разорвалось что-то непостижимое, чудовищное, яростное и бесконечно 
смертельное; что-то, прерывающее мир и останавливающее время; что-то ярчайшее и грозное, словно конец реальности и огонь гнева"). To apokaliptyczne wydarzenie, zgodnie z postmodernistyczną wykładnią, zyskuje jednak groteskowe ramy: $z$ jednej strony przynosi śmierć, zamienia rzeki w trujące mokradła, anihiluje jakiekolwiek formy życia, $\mathrm{z}$ drugiej jednak zostaje natychmiast wyparte i zbagatelizowane (w Niżejansku nikt o nim nie wie, w Jakucji określa się je jako „pewne promieniowanie"). Jego paradoksalność podkreśla sposób, w jaki Żukauskas przedostaje się z powrotem do Jakucka - po tym, jak wyskakuje ze spadochronem z bombowca, spotyka przejeżdżającego nieopodal na motorowerze mężczyznę, który oferuje mu transport do stolicy regionu.

Tkanką domykającą postkolonialny kontekst utworu jest przedstawiana sieć powiązań topograficznych. Bohaterowie przemierzają olbrzymią przestrzeń, trafiają do kolejnych miejscowości, które reprezentują różne aspekty kolo nizowa nia się. Decydujące znaczenie dla kształtu osad, wsi i miast mają czynniki ekonomiczne, społeczne i kulturowe. Podróż umożliwia prześledzenie kolonizacyjnego ruchu i dostrzeżenie wywoływanego przez niego pęknięcia. W pierwszej miejscowości, którą jest znajdujący się za kołem podbiegunowym Kjusjur (Кюсюр), Żukauskas i Gołowko trafiają do szamanistycznego ułusu, który niejako wyklucza się z imperialnego rejestru: poznani w nim bohaterowie zgodnie z postmodernistycznym, zaczerpniętym $\mathrm{z}$ buddyzmu zen oczekiwaniem (widocznym również między innymi w Małym palcu Buddy Pielewina) oddają się kontemplacji pozwalającej odkryć prawdziwą naturę rzeczy. W tym paradygmacie centralne miejsce zajmuje pustka, a wszelkie przedmioty zostają zredukowane do roli pozbawionych znaczenia atrybutów. Nie oznacza to jednak, że wyrzucony daleko poza ramy zachodniej cywilizacji ułus nie jest objęty kolonialnymi wpływami; jedynym źródłem dochodu szamanów jest sprzedaż ośrodkom zewnętrznym charakteryzujących się narkotycznym działaniem owoców że - „Жэ - это прекрасный летний цветок, распускающийся назаре; это - сердце тундры. Мы продаем их и получаем электричество, покойиуют”. Ta modelowa dla gospodarki kolonialnej transakcja de facto decyduje o kształcie utworu, jest podstawowym bodźcem ekonomicznym dla wszystkich prezentowanych w nim stronnictw - niezależnie od stopnia ich rozwoju i podejmowanej aktywności politycznej i społecznej. Groteskowy wątek główny opiera się na chęci wymiany wszelkich posiadanych przez Jakucję bogactw na pieniądze i zmianę klimatu, która umożliwiłaby uprawę ananasów i palm. Szamani z Kjusjuru, wypierając istnienie świata zewnętrznego, właściwie ugruntowują kolonialny model i kompromitują reprezentowane idee.

Pustce Kjusjuru odpowiada absurdalne symulakryczne wypełnienie kolejnego celu podróży bohaterów - Mirnego. Miasto położone w głębi lądu przeobraża się w metropolię, która pod względem estetycznym i strukturalnym wpisuje się w pełni we wzorce znane z literatury cyberpunku. Skonfrontowanie tych dwóch przestrzeni pozwala nie tylko na zestawienie dwóch modi bycia jako takiego - przede wszystkim zwraca się ku dwóm przeciwstawnym biegunom estetyki i ontologii postmodernistycznej. Jeden z nich tworzy pustka, pod wieloma względami zbieżna z pustką 
w odczuciu buddyzmu, drugi - ciąg symulakrów charakterystycznych dla kultury późnego kapitalizmu. Właśnie cyberpunk, zdaniem Frederica Jamesona, najpełniej oddaje nastrój „globalnej paranoi” ${ }^{16}$. Jegorow bardzo zręcznie odtwarza z kolei nie tylko wizualne aspekty gatunku, lecz także sieć jego ekonomicznych zależności metropolia powstaje dzięki nielegalnej sprzedaży jakuckich diamentów i zainwestowaniu wszystkich środków we własny rozwój, co doprowadza do gigantycznych dysproporcji między Mirnym a resztą regionu. Co znamienne, miasto staje się emanacją boga, przeradza się w kolejny autonomiczny dyskurs:

Вот так все возникает, и является бог, и становится всем, чем угодно, и нет ничего невозможного, и нет другого пути. Его бог есть любовь его жителей, сверкание его небоскребов, высшее число его денег, глянец его журналов. Его бог есть прекрасный город, похожий на мечту о нем, говно его уборных, отбросы его помоек, и изумруды его красавиц. Его бог есть так же, как есть что-то еще, как есть он, как есть его фонарь, его окно, его свет. Его бог заключен в его имени, которое есть слово, написанное на здании его аэропорта. И в конце концов, после всех путешествий, смеха и реки, только этот город может существовать. Замба! В следующий раз Мирный был сотворен именно так.

Wszystkie pozostałe lokacje plasują się między tymi dwoma skrajnymi punktami myśli postmodernistycznej (i jednocześnie — pod względem ekonomicznym i kulturowym — myśli postkolonialnej). Są jednostkami złożonymi z komponentów dostępnych w tych dwóch (pozornie) przeciwstawnych katalogach, wzbogaconymi o odpowiednie emanacje aparatu dyskursu. To dlatego w Ałdanie, który wkrótce zostanie zmieciony z powierzchni ziemi, tak wyczuwalne są pustka i konflikt dwóch przeciwstawnych racji, w Jakucku wieżowce wieszczą wielką przyszłość niepodległemu państwu, a rozgardiasz Niżniejanska świetnie współgra z elementami socrealistycznej przestrzeni. Wkrótce dochodzi jednak do obnażenia symulakryczności wszystkich tych elementów - okazuje się, że Mirny to jedynie miraż, mamiąca wzrok przyjezdnych olbrzymia wioska potiomkinowska (również ten motyw kulturowy nosi czysto kolonialny charakter), drugi biegun - Kjusjur - sam wyłącza się z paradygmatu istnienia, a kategorie pośrednie, $\mathrm{w}$ obawie przed zaistnieniem historii, nigdy się na nie nie decydują. Przez dekonstrukcję charakterystycznych dla postmodernizmu toposów po raz kolejny dochodzi do tryumfu postmodernizmu - pustka staje się początkiem i końcem układu, wypełnia go w całości i nie pozwala jakiemukolwiek zjawisku wyjść poza swój obręb.

\section{Bibliografia}

Deleuze, Gilles, Félix, Guattari. 2017. Anty-Edyp Kapitalizm i schizofrenia. Przeł. Tomasz Kaszubski. Warszawa: Wydawnictwo Krytyki Politycznej.

Jameson, Fredric. 2011. Postmodernizm, czyli logika kulturowa późnego kapitalizmu. Przeł. Maciej Płaza. Kraków: Wydawnictwo Uniwersytetu Jagiellońskiego.

16 F. Jameson, Postmodernizm, czyli logika kulturowa późnego kapitalizmu, przeł. M. Płaza, Kraków 2011, s. 38.

Miscellanea Posttotalitariana Wratislaviensia 8, 2020

(C) for this edition by CNS 
Kłosiński, Krzysztof. 2008. „Sarkazmy”. W: Roland Barthes, Mitologie. Przeł. Adam Dziadek. Warszawa: Aletheia.

Markowski, Michał P. 1997. Efekt inskrypcji. Jacques Derrida i literatura. Bydgoszcz: Studio $\Phi$ \& Wydawnictwo Homini.

Žižek, Slavoj. 2001. Wzniosły obiekt ideologii. Przeł. Joanna Bator, Paweł Dybel. Wrocław: Wydawnictwo Uniwersytetu Wrocławskiego.

Радов, Erop. Якутия, http://www.kulichki.com/moshkow/akm/txt/radov/yakutia-1.html (dostęp: 23.07.2018).

Эткинд, Александр. 2013. Внутренняя колонизация. Имперский опыт России. Москва: Новое литературное обозрение.

Przyjęto do druku/Accepted for publication: 30.11 .2020

Miscellanea Posttotalitariana Wratislaviensia 8, 2020

(C) for this edition by CNS 